\begin{tabular}{lc}
$\begin{array}{c}\text { Yanbu Journal } \\
\text { of }\end{array}$ & \\
$\begin{array}{l}\text { Engineering } \\
\text { and Science }\end{array}$ & Vol. 10, June 2015 (1436H) \\
\hline \hline ISSN: $1658-5321$ & www.yjes.org.sa
\end{tabular}

\title{
THE EFFICIENCY OF USING STEEL FIBERS TAKEN FROM OLD TIRES IN POLYMER CONCRETE COMPARED WITH IMPORTED FIBERS
}

\author{
Sheelan M. Hama Al - Barazinji \\ College of Engineering, Anbar University, Iraq \\ Email:drsheelan@yahoo.com
}

\begin{abstract}
This research includes a study of the effect of adding steel fibers extracted from old tires from cars (which are now available in abundance in Iraq) to polymer concrete. The efficiency of these fibers is compared with imported fibers. These two types of fibers were added with percentages of concrete volumes. These percentages were (1\%), $(1.5 \%)$ and (2.0\%). Reference concrete mix without fibers was also made for comparative purposes. Results proved that adding steel fibers with these percentages, regardless of their source, lead to improvements in all tested properties of concretes in comparison to concrete samples without fibers. The results were compared with conventional concrete. It was observed that concrete specimens with steelfiber (regardless of its type) increased its compressive strength approximately by $3-15 \%$, its splitting tensile strength by $30-70 \%$, and its flexural strength by 39-91\%. The improvement in flexural and splitting tensile strengths appeared more clearly. However, the results did not show any clear differences regarding the impact of either type of fiber (extracted and imported) meaning that the use of this fiber (from old tires) is more economical, in addition to being a solution to the problems caused by waste tires and a contribution in the protection of the environment and the society.
\end{abstract}

Keywords: Recycles steel fiber, Polymer concrete, Post crack, Flexural, Splitting tensile strengths.

\section{INTRODUCTION}

Concreteis the most extensively used construction material in the world. Concrete possesses a very low tensile strength, limited ductility and little resistance to cracking. It has been found that different type of fibers added in specific percentage to concrete improves its mechanical properties and the serviceability of the structure. Fiber reinforced concrete may be defined as a composite materials made with Portland cement, aggregate, and incorporating discrete discontinuous fibers. It is now well established that the addition of fibers plays an important role in theimprovement of the mechanicalproperties of concretewhich can be briefly reviewed as follow:

- Fibers, aligned in the direction of the tensile stress, may bring very large increases in direct tensile strength, as high as $133 \%$ for $5 \%$ of smooth, straight steel fibers [1]. An increase of the order of 30 to $40 \%$ was reported for the addition of $1.5 \%$ by volume of fibers in mortar or concrete [2].Splittingtension test of steel fiber concrete show similar result [1].

- Fibers have little effect on the static compressive strength of concrete. Thestatic compressive strength of concrete, with increases in strength ranging from nil to 
perhaps 25\%. However, the fibers do substantially increase the post-cracking ductility, or energy absorption of the material [3].

- Steel fibers are found to have much greater effect on the flexural strength of steel fiber concrete than on the compressive, with increases of more than $100 \%$ having been reported. The increases in flexural strength are particularly sensitive, not only to the fiber volume, but also to the aspect ratio of the fibers, with higher aspect ratio leading to larger strength increases [1].

- For all of the empirical measures of toughness, fibers with better bond characteristics (i.e. deformed fibers, or fibers with greater aspect ratio) give higher toughness values than do smooth, straight fibers at the same volume concentrations [4].The steel fibers do lead to major increases in the post-cracking behavior or toughness of the composites, and

- The addition of steel fibers to concrete can improve the tensile strength and ductility, but it will also reduce the workability [5].

Advancement in technology enhances not only human comforts but also damages the environment. Today the construction industry is in need of finding cost effective materials to increase the strength of concrete structures. The increasing amount of waste tyres makes the disposition of tyres a relevant problem to be solved. Waste tyres pose a health hazard since tyre piles are excellent breeding grounds for mosquitoes. Waste tyres also pose a serious fire hazard since they are easy to ignite. In addition, a large tyre fire can smolder for several weeks or even months, sometimes with dramatic effects to the surrounding environment.
Using steel fibers extracted from waste tyres in concrete, it would be the best way to make these tyres more economical and more environmentally friendly, besides improving concrete engineering properties.

Recently some research has been devoted to the use of granulated rubber and steel fibers recovered from waste tyres in concrete. Many authors concluded that the concrete obtained by adding recycled steel fibers from scrap tires showed a good improvement of the mechanical properties of the material such as tensile strength, energy absorption and toughness as well as fatigue strength [6], [7]; this material appears to be a promising candidate for both structural and nostructural applications. Centonzeet. al. [8] investigated the bond behavior between steel bar and recycled steel fiber (from waste tires) reinforced concrete. They drew the following conclusions:

- The bond failure for all tested specimens (plain and reinforced concrete) occurred by splitting; and the crack width of the reinforced samples decreases if compared to the values referred to the plain concrete;

- The bond mechanisms do not change when recycled steel fibers are added to the concrete mix.

- The presence of fibers in the concrete mix does not affect the maximum bond strength but it seems to be able to improve the bond performance after the peak bond stress is attained.

\section{EXPERIMENTAL PROGRAM}

\subsection{Materials}

- Cement: Ordinary Portland cement Type I, supplied from Taslooja factory, is used. The cement complies with Iraqi specification no.5/ 1984 [9].

- Fine Aggregate: Natural sand from the western region in Al-Anbar Governorate 
was used in the production of concrete specimens used in this work. The results of sieve analysis of this sand are shown in Table 1. Specific gravity and absorption of fine sand used were calculated according to ASTM - C 128-88 [10] and they were equal to 2.66 and $3.6 \%$ respectively. The sulfate content was equal to $0.32 \%$.

- Coarse Aggregate: Crushed coarse aggregate from the western region in $\mathrm{Al}-$ Anbar governorate was used for all concrete mixes in this work. The aggregates were conformed to the requirements of the Iraqi specification No. 45-99 [11]. Specific gravity was equal to 2.79 and sulfate content was equal to $0.071 \%$. The results of sieve analysis of this coarse aggregate are shown in Table 2.

- Mixing Water: Ordinary tap water was used in this work for all concrete mixes and curing of specimens.

- Steel Fibers: Steel fibers with (30) $\mathrm{mm}$ in length and (0.6) $\mathrm{mm}$ in diameter were produced by cutting steel wire taken from an old car's tyre are used in this work as shown in Figure 1, besides imported steel fibers. The properties of both types of fibers, which have been tested, are listed in Table 3.

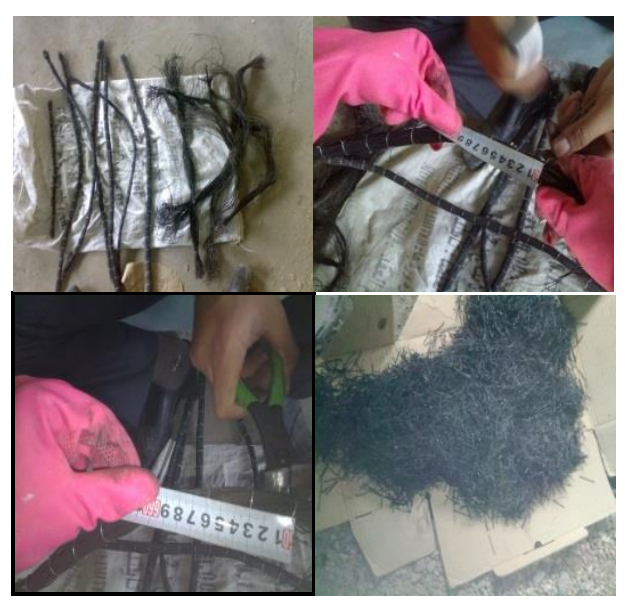

Fig.1. Recycle steel fibers
Tests are carried out in a civil engineering laboratory at Anbar University.

- Polymer: Styrene butadiene rubber (SBR) is used as polymer modifier in this work. This polymer is usually a milky-white fluid. The Gulf International Chemicals Company, Oman, manufactured this polymer and the typical properties of SBR polymer are listed in Table 4.

TABle 1: Grading Of Fine Aggregate (SAND)

\begin{tabular}{|c|c|c|}
\hline Sieve size (mm) & \%Passing & $\begin{array}{c}\text { Limits of Iraqi specification } \\
\text { No.45/1984 } \\
\text { \% passing (Zone No. 1) }\end{array}$ \\
\hline 10 & 100 & 100 \\
\hline 4.75 & 92 & $90-00$ \\
\hline 2.36 & 77 & $60-95$ \\
\hline 1.18 & 67 & $30-70$ \\
\hline 0.6 & 33 & $15-34$ \\
\hline 0.3 & 10 & $5-20$ \\
\hline 0.15 & 6 & $0-10$ \\
\hline
\end{tabular}

TABLE 2: GRADING OF COARSE AGGREGATE (GRAVEL)

\begin{tabular}{|c|c|c|}
\hline Sieve size (mm) & $\begin{array}{c}\text { Coarse } \\
\text { aggregate } \\
\text { \% passing }\end{array}$ & $\begin{array}{c}\text { Limits of Iraqi Specification } \\
\text { No. 45/1984 }\end{array}$ \\
\hline 12.5 & 100 & 100 \\
\hline 9.5 & 96 & $85-100$ \\
\hline 4.75 & 28 & $10-30$ \\
\hline 2.36 & 6 & $0-10$ \\
\hline 1.18 & 1.5 & $0-5$ \\
\hline
\end{tabular}

TAble 3: Properties Of Used Steel Fibers

\begin{tabular}{|c|c|c|}
\hline \multirow{2}{*}{ Property } & \multicolumn{2}{|c|}{ Specification } \\
\cline { 2 - 3 } & Recycle steel fiber & $\begin{array}{c}\text { Imported steel } \\
\text { fiber }\end{array}$ \\
\hline Density & $7800 \mathrm{~kg} / \mathrm{m}^{3}$ & $7860 \mathrm{~kg} / \mathrm{m}^{3}$ \\
\hline Ultimate strength & $1500 \mathrm{MPa}$ & $1550 \mathrm{MPa}$ \\
\hline Length & $30 \mathrm{~mm}$ & $30 \mathrm{~mm}$ \\
\hline Diameter & $0.6 \mathrm{~mm}$ & $0.5 \mathrm{~mm}$ \\
\hline Aspect ratio & 50 & 60 \\
\hline
\end{tabular}

TABle 4: Properties Of SBR Polymer

\begin{tabular}{|c|c|}
\hline Properties & Description \\
\hline Appearance & White emulsion \\
\hline Specific Gravity & $1.03 \pm 0.02 @ 25^{\circ} \mathrm{C}$ \\
\hline PH Value & $9 \pm 2$ \\
\hline Freeze/Thaw Resistance & Excellent \\
\hline Chloride Content & Nil \\
\hline Flammability & Non-flammable \\
\hline Compatibility & Can be used with all types of portland cement \\
\hline
\end{tabular}




\subsection{Preparation of the Concrete Mix}

The mixing operations were made in the concrete laboratory at the Civil Engineering Department at Anbar University. A $0.1 \mathrm{~m}^{3}$ pan mixer was used. First, the coarse aggregates and the fine one are poured and mixed. Then the cement is poured in and dry mixed with the coarse and fine aggregates while adding the fibers until a homogenous dry mix is obtained.

After that the water is added and the mixing continued until a final homogenous mix is obtained. The concrete mix is poured, in three layers, in the molds. An electrical vibrator makes compaction for not more than $10 \mathrm{sec}$. The specimens are unmolded after 24 hours in laboratory. They are submerged in water for the time of test. Mixes details are listed in Table 5. The workability of concrete mixes was observed by the slump cone test and, in order to minimize variations in workability, the compaction energy was varied to obtain proper compaction. The mixing procedure and time were kept constant for all the concrete mixes investigated.

\subsection{TeSt PRogram}

\section{- Compressive Strength Test}

Compressive strength was determined using $(150 \times 500) \mathrm{mm}$ cylinders according to ASTM C39-05[12]. The average compressive strength of three cylinders was recorded for each testing age (7,14 and 28 days).

\section{- Splitting Strength Test}

Splitting strength was determined using $(150 \times 500) \mathrm{mm}$ concrete cylinders. The test was carried out according to ASTM C496-86 [13]. Average of three cylinders was obtained for each testing age (7,14 and 28) days.

\section{- Flexure Strength Test}

Flexural strength was determined using $(100 \times 100 \times 500) \mathrm{mm}$ concrete prisms. Two point load test was carried out according to ASTM C78-94 [14]. The average of three prisms was obtained for each testing age (7,14 and 28) days.

\section{- Stress - Strain Test}

The testing machine (ELE) is used for the determination of stress-strain relationship using a compressometer of a gauge length of $150 \mathrm{~mm}$ and a dial gauge of an accuracy $0.002 \mathrm{~mm}$ as shown in Figure 2.

\section{RESULTS AND DISCUSSION}

\subsection{COMPRESSIVE STRENGTH}

Figure 3 shows the relationship between compressive strength with age for different mixes. The compressive strength of all specimens increases with the increase of the percentage of steel fibers as compared to the reference one without fibers and the results of the two types of steel fibers are very close as follows; The mixes, with recycle steel fibers (SRFPC), have shown higher compressive strength compared to the reference mix by $2.9 \%, 7.4 \%$, and $10.8 \%$ for $1,1.5$ and $2 \%$ percentage of fibers, respectively, at 7 days age.

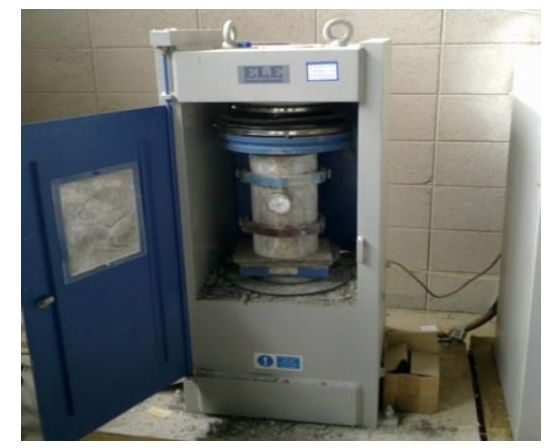

Fig.2. Stress-strain test

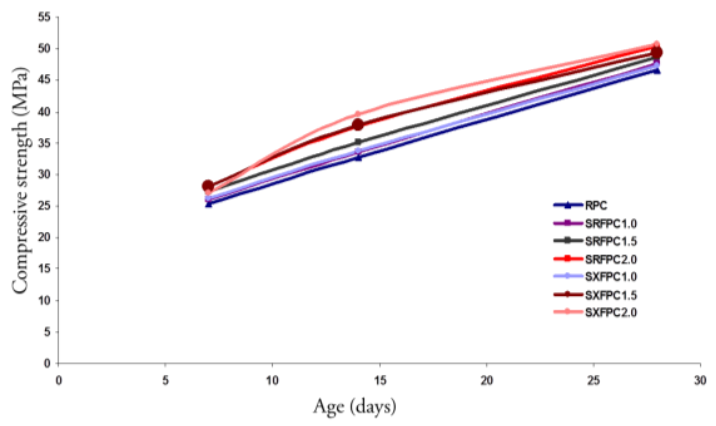

Fig.3. Relationship between Compressive Strengths and Age for all Concrete Mixes 
TABLE 5: MIX PROPORTION

\begin{tabular}{|c|c|c|c|c|c|c|c|}
\hline Symbol & $\begin{array}{c}\text { Cement } \\
(\mathbf{k g})\end{array}$ & $\begin{array}{c}\text { Sand } \\
\mathbf{( k g})\end{array}$ & $\begin{array}{c}\text { Gravel } \\
\mathbf{( k g})\end{array}$ & $\begin{array}{c}\text { Polymer } \\
\text { content(\%) of } \\
\text { cement content }\end{array}$ & $\begin{array}{c}\text { Steel Fibers } \\
(\mathbf{\%}) \text { of Mixture } \\
\text { Volume }\end{array}$ & W/C \% & $\begin{array}{c}\text { Slump } \\
(\mathbf{m m})\end{array}$ \\
\hline RPC & 350 & 700 & 1050 & 10 & 0.0 & 0.36 & 85 \\
\hline SRFPC1.0 & 350 & 700 & 1050 & 10 & 0.5 & 0.36 & 77 \\
\hline SRFPC1.5 & 350 & 700 & 1050 & 10 & 1.0 & 0.36 & 73 \\
\hline SRFPC2.0 & 350 & 700 & 1050 & 10 & 2.0 & 0.36 & 61 \\
\hline SXFPC1.0 & 350 & 700 & 1050 & 10 & 0.5 & 0.36 & 80 \\
\hline SXFPC1.5 & 350 & 700 & 1050 & 10 & 1.0 & 0.36 & 71 \\
\hline SXFPC2.0 & 350 & 700 & 1050 & 10 & 2.0 & 0.36 & 60 \\
\hline
\end{tabular}

RPC: Reference Polymer Concrete, RF: Recycle Fibersand, XF: Imported Fibers

At 14 days age, the percentages of the increases are $3.0 \%, 7.3 \%$, and $15.3 \%$ for $1,1.5$ and $2 \%$, respectively. At 28 days age, the percentages of the increases are $1.4 \%$, $3.7 \%$, and $7.1 \%$ for $1,1.5$ and $2 \%$, respectively. On the other hand, the mixes, with imported steel fibers (SXFPC), have shown higher compressive strength compared to the reference mix by $3.3 \%, 10.3 \%$, and $11.3 \%$ for $1,1.5$ and $2 \%$, respectively, at 7 days age. At 14 days age, the percentages of the increases are $3.2 \%, 15.9 \%$, and $21.4 \%$ for $1,1.5$ and $2 \%$, respectively. Finally, at 28 days age, the percentages of the increases in compressive strength are $0.7 \%, 5.0 \%$, and $7.9 \%$ for $1,1.5$ and $2 \%$, respectively. The improvement in the compressive strength of concrete may be due to the effect of the polymer to reduce w/c ratio, due to lesserentrapped air voids, the better performance of concrete mixes containing SBR, and the capability of steel fiber to delay the unstable development of microcracking. The percentages of the increases in compressive strength at early ages (7 and 14 days) are higher than those at 28 days. This may be because the fibers limit the propagation of micro-crack at early age and the composite effect of concrete and steel fibers under load, i.e associated with the steel fiber resistance to the external load [3].

\subsection{SPLiTTING STRENGTH}

Figure 4 shows the relationship between splitting strength with age. The mixes, with recycle steel fibers (SRFPC), have shown higher splitting tensile strength compared to the reference mix by $35.5 \%, 40.2 \%$, and $47.8 \%$ for $1,1.5$ and $2 \%$, respectively, at 7 days age. At 14 days age the percentages of the increases are $56.6 \%, 64.0 \%$, and $70.7 \%$ for $1,1.5$ and $2 \%$ percentage of fibers, respectively. At 28 days age, the percentages of the increases are $42.8 \%, 58.2 \%$, and $63.8 \%$ for $1,1.5$ and $2 \%$, respectively. On the other hand, the mixes, with imported steel fibers (SXFPC), have shown higher splitting tensile strength compared to the reference mix by $32.1 \%, 50.5 \%$, and $54.6 \%$ for $1,1.5$ and $2 \%$ percentage of fibers, respectively, at 7 days age.

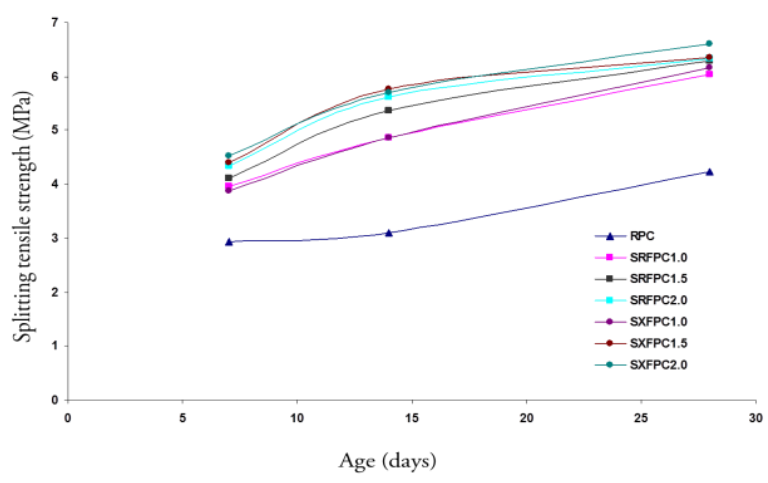

Fig.4. The Relationship between Splitting Strength and Age for all Mixes 
At 14 days age the percentages of the increases are $56.6 \%, 65.9 \%$, and $72.7 \%$ for $1,1.5$ and $2 \%$, respectively. Finally, at 28 days age, the percentages of the increases in splitting tensile strength are $45.9 \%, 59.6 \%$, and $65.0 \%$ for $1,1.5$ and $2 \%$, respectively. From the results, it can be noted that the adding of fibers to concrete with these percentages leads to improvement in the splitting strength of concrete; this improvement increases relatively with an increase in fibers percentages. These increases in splitting strength might be due to the composite effect of the polymer and steel fibers, which lead to bridge the cracks, resisting the formation of micro-crack. The high tensile strength of polymer itself leads to an overall improvement in the cement - aggregate bonds[1]. Again, the two types of fibers have the same action as compared with the one without fibers.

\subsection{FleXural Strength}

Figure 5 shows the relationship between flexural strength with age.The mixes, with recycle steel fibers (SRFPC), have shown higher flexural tensile strength compared to the reference mix by $39.0 \%, 48.3 \%$, and $60.2 \%$ for $1,1.5$ and $2 \%$, respectively, at 7 days age. At 14 days age, the percentages of the increases are $43.1 \%, 62.4 \%$, and $86.1 \%$ for $1,1.5$ and $2 \%$ percentage of fibers, respectively. At 28 days age, the percentages of the increases are $51.6 \%, 72.1 \%$, and $93.8 \%$ for $1,1.5$ and $2 \%$, respectively.

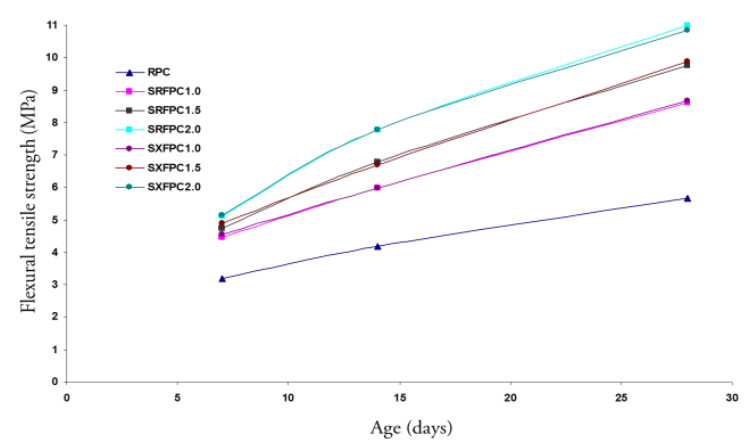

Fig.5. The Relationship between Flexural Strength and Age for all Mixes
On the other hand, the mixes, with imported steel fibers (SXFPC), have shown higher flexural tensile strength compared to reference mix by $42.6 \%, 53.9 \%$, and $60.8 \%$ for $1,1.5$ and $2 \%$ percentage of fibers, respectively, at 7 days age. At 14 days age, the percentage of the increases are $43.3 \%, 60.0 \%$, and $85.9 \%$ for $1,1.5$ and $2 \%$, respectively. Finally, at 28 days age, the percentages of the increases in flexural tensile strength are $53.1 \%, 74.1 \%$, and $91.0 \%$ for $1,1.5$ and $2 \%$, respectively. From the results, it can be seen that, the flexural strength of all specimens increases clearly with time and with increasing percentage of fibers as compared with the flexural strength of concrete specimens without fibers. It is appearing from these results that adding of fibers to concrete with these percentages leads to improvement in the flexural strength of concrete and these increasing relatively with an increasing in fibers percentages. The increase in flexural strength might be due to the bridging of the cracks, as shown in Figure 6.
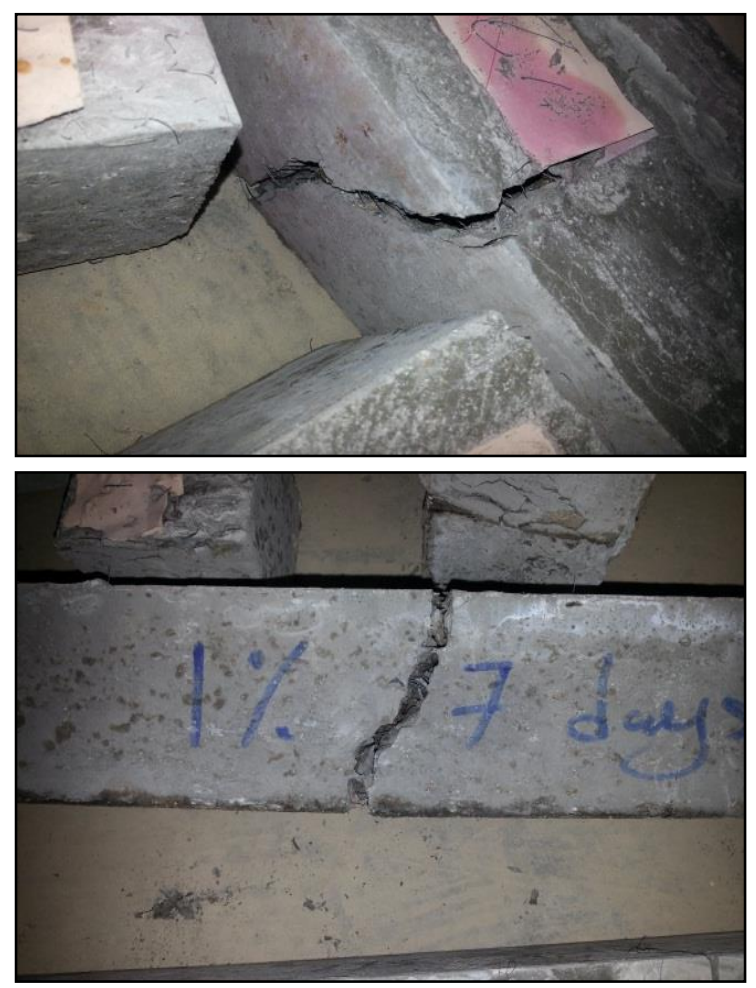

Fig.6. The Flexural Failed Specimens 


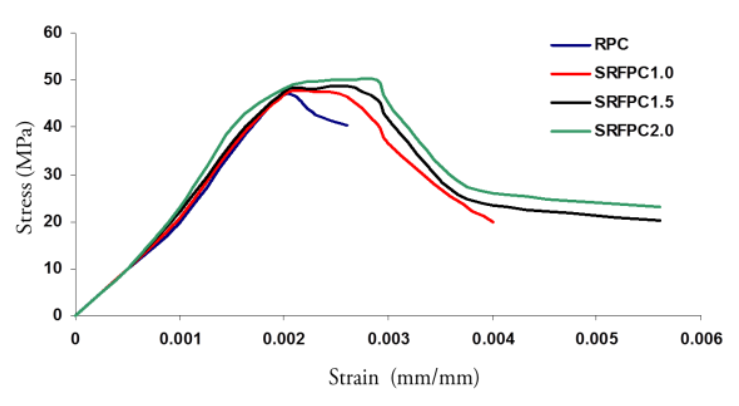

Fig.7. Stress - Strain Relationship for RPC ad SRFPC Concrete Mixes

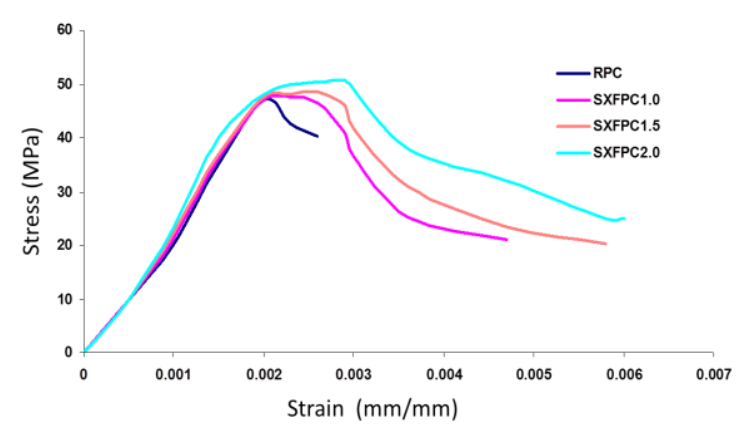

Fig.8. Stress - Strain Relationship for RPC and SXFPC Concrete Mixes

The development of the bonding property of polymer film on the surface of the concrete and the interface with other materials lead to an increase in the tensile strength of concrete and hence its flexural strength. It might also be due to the role of steel fibers in releasing fracture energy around the crack tips, which is required to extent crack growth by transferring it from side to another side [1], [2] and [4].

\subsection{STRESS - STRAIN TEST}

Figures 7 and 8 show graphically the compressive stress-strain curves of SRFPC and SXFPC. One can see that the compressive strength value is not affected by the steel fibers as compared to the plain concrete[1]. On the other hand, the concretes specimens reinforced with higher contents of fibers show a more extended softening branch, i.e. the increase in fibers content increases the area under curves as shown in Figures 7 and 8, which mean that the fibers substantially increase the post-cracking ductility, or energy absorption of the material. One can only see that the two types of fibers (the recycled and imported fibers) gives the closely results [3] and [4].

\section{CONCLUSION}

According to the results of this work, one can see that the mechanical properties of concrete like compressive strength, splitting tensile strength, flexural tensile strength and stress strain relationship, for both types of fibers (recycle steel fibers and imported steel fibers), are close, compared with the reference mix without fibers. In addition to improving concrete's engineering properties, using recycled fibers from old tyres yields economic gains as well as environmental benefits.

\section{REFERENCES}

[1] C.D. Johnston, "Fiber reinforced cements and concretes", Advances in concrete technology volume 3, Gordon and Breach Science publishes, 2001.

[2] ACI Committee 544, 1R-96 "Report on Fiber Reinforced Concrete", Reported by ACI committee 544, Reapproved 2002, ACI Manual of Concrete Practice, 2009, pp.9-12.

[3] R.D.Neves, and J.C. Fernades de Alameida "Compressive Behavior of Steel Fiber Reinforced Concrete", Structural Concrete Journal, No.1, 2006.

[4] C.D. Johnston, "Definition and measurement of flexural toughness parameters for fiber reinforced concrete",Cem. Concr. Agg. 1982.

[5] C.C., Chang, C.T., Tsai, L.S. Li, and C.L. Hwang, "Durability Design and Application of Steel Fiber Reinforced Concrete in Taiwan", the Arabian Journal for Science and Engineering, Vol. 34, Number 1B, April 2009,pp. 57-79.

[6] M.A. Aiello, F. Leuzzi, G.Centonze, A.Maffezzoli, 2009 "Use of steel fibres recovered from waste tyres as reinforce-ment in concrete: pull-out behavior, compressive and flexural strength”, University of Salento, Italy 
[7] Mohamad Nizar Bin Abdonasrah, "Toughness of concrete reinforced with recycled tire steel fiber", Degree Thesis, UniversitiTeknologi Malaysia, 2011 .

[8] G. Centonze, M.Leone, E. Vasanelli, and M.A.Aiello, " Interface Analysis Between Steel Bars And Recycled Steel Fiber Reinforced Concrete", VIII International Conference on Fracture Mechanics of Concrete and Concrete Structures FraMCoS-8

[9] Iraqi Specifications -5, "Portland cement", the Central Agency for Standardization and Quality Control, Baghdad 1999, Page 8.

[10] ASTM, C128-88, "Standard Test Method for Specific Gravity and Absorption of Fine Aggregate", Annual Book of ASTM Standard, Mortar", Philadelphia, Vol.04-02, 1989, pp. 6871.

[11] The Iraqi Standard No. 45, "The ruins of the natural resources used in concrete construction," the Central Agency for Standardization and Quality Control, Planning Council, Baghdad 1999.

[12] ASTM: C39-01, "Compressive Strength of Cylindrical Concrete Specimens", American Society of Testing and Material International, 2005.

[13] ASTM: C496-05, "Splitting Tensile Strength of Cylindrical Concrete Specimens", American Society of Testing and Material International, 2005.

[14] ASTM: C78-05, "Flexural Strength of Concrete (Using Simple Beam With Third-Point Loading", American Society of Testing and Material International, 2005. 


\title{
كفاعةُ استخدام الأليافِِ الفولاذيةِ المستخلصة مِنْ الإطاراتِ القديمةِة في الخرسانةِة البوليمريهه مقارنه باستخدام الالياف المستورده
}

\author{
شيلان محمود حمه البرزنجي \\ كليه الهنسة، جامعة الانبار، العراق
}

الملخص:

يتضمن هذا البحث دراسة تأثير اضافة نواتج التقطيع اليدوي للاسلاك المستخلصة من الاطارات القديمة للسبار ات ( المنوفرة حالياً بكثرة في العراق) كألياف حيديدية مضافة الى الخرسانة البوليمرية وبنسب من حجم الخلطة على مقاومة الخرسانة للانضغاط ، الانثناء، الانشطار، منحنى الاجهاد_الانفعال. تمت اضافة الالياف الحديدية بنسب (1\%)، (1.5\%) و (2.0\%) من حجم الخلطات الخرسانية، وتم مقارنتها مع خلطات خرسانية تحتوي على نفس النسب من الياف الحديد المستوردة، كما تم استخدام خلطة خرسانية مرجعية خالية من الالياف

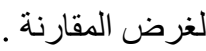

أظهرت النتائج تحسناً في الخواص الميكانيكية للخرسانة الحاوية على الالياف حبديدية مقارنة بالخرسانة المرجعية. بالمقارنة مع الخرسانةِ التقليديةٍ لوحظ بأنّ النماذج الخرسانيةٍ المسلحه بالليافِ الفولاذِِة (بغض النظر عن نوعِه) زادَت مقاومة إنضغاطها تقريباً من 3-15\% ومقاومة الثندّ حو الي 30-70 \%. بينما الزيادة في مقاومه الانثناء حوالي 39-91\%. وكان التأثير الاكثر وضوحاً في تحسين مقاومة الانثناء و الانشطار للخرسانة الحاوية على الالياف. النتائج لم تظهر فروقات واضحة بين ناثير كلا النوعين من الألياف (المستخرج و المستورد)، أي ان استخدام هذه الالياف يعتبر أفضل من الناحية الاقتصادية، إضافة الى كونها حلا لمشاكل بيئية تسببها نفايات الإطار ات و هذا يساهم في حماية البيئة و المجنم. 